\title{
Tracking and Explaining E-Participation in India
}

\author{
Rajeev Gowda ${ }^{1}$ and Hemangini Gupta ${ }^{2}$ \\ ${ }^{1}$ Economics and Social Sciences, Indian Institute of Management Bangalore, \\ Bannerghatta Road, Bangalore 560076, India \\ gowda@iimb. ernet. in \\ ${ }^{2}$ Women's Studies Department, Emory University, \\ 550 Asbury Circle, Candler Library Suite 128, Atlanta, GA 30322, USA \\ hemanginig@gmail.com
}

\begin{abstract}
India has recently witnessed various initiatives that harness information and communication technologies (ICTs) to promote electoral reform and political mobilization. These efforts have been initiated mainly by non governmental organizations drawn from India's urban, English-speaking, upper and middle classes. These efforts have been focused on non-partisan process improvements or short-lived political mobilization with limited success. We analyze these initiatives against the backdrop of modern India's political evolution which has seen the marginalization of upper and middle classes in politics. We see technology as central to the re-engagement of ICT-savvy upper and middle classes with the political sphere. We suggest that political neutrality may be an effective and appropriate strategy for India's upper and middle classes in the pursuit of their policy agendas.
\end{abstract}

Keywords: India, Political Mobilization, Registration, Reform, Middle and Upper Class E-Participation.

\section{Introduction}

In many countries including India, Information and Communication Technologies (ICTs) are being utilized by citizens, organizations and governments to engage with political processes. Norris (2003) has articulated how ICTs can improve direct democracy (through, e.g., electronic voting on referenda), representative democracy (through improving the quality of representation and helping elected representatives perform more efficiently), and pluralist democracy (through facilitating the mobilization of multiple interests to influence the political process, including through the formation of new political parties). In this chapter we focus on the Indian experience with regard to how ICTs have been harnessed by citizens and civil society groups to enhance the quality of representative democracy.

In the following sections, we describe the e-initiatives and online mobilizations, which have sought to address issues of political reform, engagement and mobilization in India. In the next section, we examine these efforts and classify them along three dimensions: 1) issues related to voting and electoral rolls 2) dissemination of candidate and voting information 3 ) agenda setting and policy framing. In the section 
that follows, we seek to examine the ways in which e-initiatives have had explicitly political purposes, such as the mobilization of voters, the launch of new political parties or to trigger public responses to controversial political developments. In the section after, we lay out the larger Indian political context so as to better comprehend the nature of voter engagement and the larger implications of Internet access and a well-established IT industry. In our final section, we frame the initiatives discussed in the initial sections against the backdrop of the Indian context and attempt to analyze India's fast-evolving e-landscape and those who take advantage of it for political purposes.

\section{Civil Society E-Democracy Initiatives in India}

\subsection{Voting and Electoral Rolls}

The responsibility for conducting elections in India rests with the Election Commission of India (ECI). It is an independent, constitutionally-sanctioned authority responsible for conducting free and fair elections as well as ensuring voterregistration. The standard procedure for voter registration involves physical verification of the voters' claimed place of residence by ECI representatives (Gowda, 2007); however, recently, the ECI has experimented with online voter registration, subject to physical verification. The ECI also uses the web to put into the public domain all the information that the candidate is obliged to share such as his/her educational accomplishments, assets and liabilities and criminal records, if any. Judicial references and election laws are also available online. The website has been fairly popular in terms of the hits it has received, and the ECI has been widely appreciated for its move towards enhancing transparency and user-friendliness.

However, in spite of the ECI's attempts to register India's millions of voters, there remain substantial gaps in electoral rolls. Omissions are rife in urban areas, where people tend to remain unregistered because of migration, or not being present at home when ECI verification is conducted (Ramanathan, 2008). In recent years, urban residents, particularly the educated middle and upper classes, have complained that the process of registering to vote itself is cumbersome (requiring people to demonstrate proof of residence at particular election centers at particular times on certain dates). This dissatisfaction with the enrolment process has been identified as the key barrier to participation by the educated middle and upper classes. In order to redress this problem, a private sector corporation came together with a nongovernmental organization and embarked on a campaign to make the voter registration process smoother for the electorate by using ICTs. This campaign is described below:

\subsubsection{Jaago Re}

Jaago $R e$ (literally translated to "Wake up" in Hindi) was a campaign targeted at overcoming voter apathy ahead of the 2009 General Election. Jaago Re has been the tag line used in advertisements by Tata Tea to promote its products, starting in 2007. In 2008 the company decided to address the issue of voter apathy. Working together with the independent non-governmental organization (NGO) Janaagraha, the Jaago 
Re campaign was an all-India effort primarily conducted online through the website (www . jaagore. com). It provided voters with the information necessary for them to enroll as voters. Although essentially aimed at first time voters and youth, it billed itself as a movement for change via 'active participation in the democratic process.' Once registered, members received information regarding the status of their voter registration and news about the elections and candidates.

Tata Tea treated Jaago Re as a component of its marketing strategy and not as a corporate social responsibility initiative. It engaged the services of a leading advertising agency and put out television and print advertisements. The Jaago Re One Billion Votes campaign managed to secure or assist in over 600,000 voter registrations all over India. Its website received over 16 million visitors and 5 million registrations; thus the campaign can be termed a success in terms of its overall impact and presence (Pinglay, 2009).

\subsection{Voting Choices and Information}

\subsubsection{Association for Democratic Reforms}

The next step in the process of voter-mobilization is provision of access to information about political candidates and parties. Given that India's party system is increasingly characterized by fragmentation and multiparty coalitions (Gowda and Sridharan, 2007), it has become difficult for voters to obtain detailed information about candidates and party manifestos. Despite the media's role in disseminating information, lack of adequate information on candidates has raised concerns regarding the quality of representatives in legislatures. For instance, over the last decade, many political parties have chosen to field candidates with criminal records. Further, corruption has increased across the board and voters are hard pressed to sift through candidates who might have amassed wealth through illegitimate means during their term in office.

If voters are to make an informed choice, it is necessary that they be provided with more information about candidates' antecedents and also about parties' manifestoes and track records. Recognition of this point led an independent organization called the Association for Democratic Reforms (ADR) to file a Public Interest Litigation (PIL) in the Supreme Court of India. This effort is a prominent example of citizen activism that resulted in policy change and improvement in the quality of India's democracy (Sastry, 2004). In its own words, the ADR “continues to works towards strengthening democracy and governance in India by focusing on fair and transparent electoral and political processes."

After a long drawn-out battle lasting four years, the Court ruled in favor of disclosure, and declared that candidates must release complete information on their financial, educational and criminal background (if any). Following this verdict and its enactment into law by parliament, the ADR has spearheaded a national 'Election Watch' campaign (detailed below), which has a significant online component. It works with 1200 NGOs across India in an effort toward improving the electoral process in India. The ADR and its partners have also been instrumental in obtaining a ruling from the Central Information Commission in 2008 to the effect that income tax returns of political parties will be made available in the public domain. 


\subsubsection{National Election Watch}

The National Election Watch campaign operates both online (www.nationalelectionwatch.org) and offline and aims to provide voters with: (i) Information on candidates' finances, education and criminal records, based on their sworn affidavits; (ii) Feedback from the public about the work done by their elected representatives; (iii) Data on the state of a constituency measured on human development index parameters; (iv) Ratings of various representatives based on peoples' comments and the demonstrable improvements in their constituencies during their tenure, etc. and (v) A channel to provide feedback to elected representatives, so that they are better informed about constituents' priorities and concerns.

Apart from maintaining a constant vigil on the activities of the elected representatives, the Election Watch campaign seeks to facilitate an online dialogue between the representative and his constituents, enabling the public to evaluate the performance of elected representatives. The Election Watch campaign gets its information mainly from the affidavits of the candidates or by means of petitioning the Election Commission and the government under the Right to Information (RTI) Act which makes it mandatory for the Government to provide relevant information to applicants.

Although its impact on voters is hard to measure, the Election Watch has arguably played a pivotal role in recent improvements in the quality of political representation. For instance, the state of Bihar, for the first time in decades, has no criminally tainted minister in the council. This is because the Chief Minister refused to include anyone with a criminal record in the cabinet and the ready availability of such information in the public domain allowed the press and the public to check on whether he had indeed lived up to his assurance. In Gujarat state, an Election Watch report spurred the Election Commission into investigating candidate's affidavits and initiating proceedings against those who had supplied false information. The number of candidates with serious offenses in the Karnataka state elections came down from 217 in 2004 to 93 in 2008. Above all, major political parties such as the Indian National Congress (Congress) and the Bharatiya Janata Party (BJP) have started examining the records of applicants before nominating them as party candidates.

The internet has been the main medium through which ADR and National Election Watch have communicated the information they receive and the measures they take to the public. It has also been instrumental in stirring up public support for programs and initiatives. Election Watch information is now regularly being used by mainstream media as they profile (usually) "big players" fighting the elections in constituencies that would interest their readers/viewers. Details of financial information are highlighted in mainstream press articles, which garner significant attention, especially if it appears that the financial information provided seems unlikely or dubious, e.g., an understatement of assets by candidates publicly regarded as particularly wealthy.

\subsubsection{Liberty Institute's Empower India initiative}

Even in smaller towns across India, local media are picking up the information about candidates available online and using it to increase awareness amongst voters. Barun Mitra at the Liberty Institute, which conducts research and advocacy on policy issues including democracy and governance (online at www. Empower India.org) makes an interesting observation in this regard. During the 2007 State Assembly elections, 
he found that a number of local media collectives and the panchayats (local governments) had used the candidate-background information available on Empower India's website. According to Mitra, it is the poor who sustain democracy, and resources such as these played a very important role in helping them assess the integrity and honesty of elected representatives. He noted that there was more eagerness for candidate information from slum-dwellers in Delhi rather than from a more affluent audience in Kerala. The Kerala audience was privy to the same information, but only saw the service being provided as a website, not as a handle to enhance democratic functioning (Bawa, 2009).

\subsubsection{Smart Vote}

Another civil society initiative that emerged during the 2009 parliamentary election is 'Smart Vote,' a campaign aimed at using the medium of the internet to enhance the quality of democracy in India by giving voters the means to make a more informed choice. It states as its vision the need to improve the quality of elected representatives. It identifies the parochial mindset of the typical voter as the major impediment to choosing accountable elected officials. Voting choices are made in favor of a party irrespective of the record of the candidate or simply in order to punish the incumbent government. The campaign primarily uses its website and other online media to get across its message. It offers information on the constituency as well as the candidates contesting from it, including past statements and current interviews.

The site also informs citizens about their representatives, their records in parliament, salary and allowances along with other pertinent data. While it is difficult to gauge the site's impact on voters' electoral choices, Smart Vote, in alliance with a television channel, pioneered live, interactive debates between political candidates for the first time in India during the 2009 parliament election. As these debates provided an interface for live interaction of candidates and voters this Smart Vote initiative significantly enhanced candidates' availability and accessibility.

\subsection{Policy Analysis and Priority Setting}

\subsubsection{Parliamentary Research Service}

Parliament sessions are filmed and broadcast on a State-run TV channel. Yet, detailed information about bills being considered by parliament is not easy for the public to access. Neither is analysis of the bills easily available to the public. Analysis in the mass media can suffer from lack of sufficient depth, or can represent partisan viewpoints. This problem is shared by other key stakeholders including members of parliament and the media. Because of the use of the party "whip" which mandates that members must vote in line with the party, and the hurried passage of many bills in parliament (Madhukar, 2008) even members of parliament sometimes have little information about what they are voting for or against (Yadav, 2008).

In order to address this problem, a civil society initiative led to the establishment of the Parliamentary Research Service (PRS, online at http://www.prsindia.org/), modeled on the lines of the non-partisan Congressional Research Service in the United States of America. PRS is an independent body that has taken on the challenge of decoding and simplifying bills into 3-4 page briefs which are then circulated to all Members of Parliament, media houses, the top 500 Indian corporations, and also 
displayed on the PRS website. The website aims to make it easy for the press and the public to understand the nature and implications of bills under consideration in Parliament. Comments from stakeholders are also directed to the relevant Minister.

Members of Parliament, across party lines have welcomed the information generated by PRS and credited it with helping them perform their legislative roles better (Srivastava, 2007). Further, the information provided by PRS has enabled greater transparency about the performance of Members of Parliament. Media coverage of PRS's detailed reports on the actual attendance and participation of Members of Parliament also puts pressure on members of parliament to maintain accountability to voter constituencies.

\subsubsection{Praja}

ICTs have also been used to help determine what issues and priorities are of concern to voters. This contrasts with the traditional top-down process whereby the candidate offers a platform and the voters' role is limited to a yes/no choice for or against that candidate. The group, Praja (meaning 'citizen') conducts online activities to link citizens with each other. It provides a common online platform (a moderated, discussion board) to discuss governance issues. Praja conducted a survey on the eve of the 2009 parliament election which allowed voters to identify issues that they considered crucial in this election at both the State as well as national levels. Candidates were later interviewed by representatives of the website on these topics, and the interviews were made public on the website. Praja has allowed citizens within communities to access information through a process of mutual sharing and has enabled collective action by uniting people with common concerns.

\subsubsection{Resurgent India}

Another NGO called Resurgent India, recruited youth over the internet to participate in a Youth Manifesto workshop prior to the 2009 parliament election. Given that India is a predominantly young country with over 70 percent of its population below the age of 35, the theme of this workshop was to assess the platforms of the major political parties from the perspective of youth. The workshop generated an alternative set of agendas - The Youth Manifesto-focused on the needs of youth. The Youth Manifesto was presented to a parliament candidate from the ruling Congress party and to a national executive member of the Bharatiya Janata Party (BJP), India's main opposition party (Gupta, 2009).

\section{ICTs and Political Activity}

\subsection{Political Competition and the Use of the Internet}

In India, although a major political party such as the BJP was using ICTs in their most basic form (text messaging, phone calls and a basic Internet presence) as early as 2003, it was not until recently that ICT usage gained prominence within election campaigns (see https://digitalcommons.georgetown.edu/blogs/ isdyahoofellow/tag/rahul-gandhi/). Limited access and low levels of usage have traditionally been the impediments to using the internet as a campaign tool. 
The BJP's 2004 "India Shining" campaign was a path breaker in this regard. The BJP allocated as much as $5 \%$ of its total campaign funds to online campaigns, which mainly targeted urban ICT- savvy voters. It revamped its campaign website, aggressively sent out text messages, pre-recorded voice clips and emails to over 20 million people. Although the campaign ended with the party being routed at the polls, the nature and mode of its campaign in 2004 set the tone for the 2009 parliamentary elections (see: https://digitalcommons.georgetown.edu/blogs/ msfs-556-spring2009/how-internet-and-mobile-technologiesare-transforming-election-campaigning-in-india/ and Mehra, 2009).

Most political parties expected Internet-based campaigning to have more impact in 2009. This is because a third of India's voters are now under the age of 25 . The weightage of the urban voter in the electoral process has also increased 2-3 fold after the recent redistricting exercise (termed Delimitation in India) as well as due to growing Internet penetration (from 16 million in 2004 to 80 million in 2009; for information about redistricting see www.delimitation-india.com). In fact, the success of Barack Obama's Internet campaign in terms of gaining supporters and raising funds has been seen as a model for future political campaigns in other countries too (Mosk, 2008).

In India the pro-BJP camp was in the forefront on the Internet in terms of content as well as sheer presence and reach. While the BJP's own website consisted mainly of its manifesto, that of its prime ministerial candidate, L K Advani had many interactive features including an active forum and a blog (www.lkadvani.in). The task set out by the BJP camp for its online initiative was to "to contact and mobilize young voters in thousands of college campuses across the country" and build a volunteer movement. There were also links to the L.K. Advani Facebook page, the Advani for PM Orkut (a social networking site) page and the BJP supporters group on Orkut had nearly 30,000 members.

The Friends of the BJP website (http://friendsofbjp.org) is run by volunteers with no formal affiliation to the party. It generated ideas for the BJP to act on, and conducted outreach efforts aimed at enabling the party to win more urban seats. Several BJP leaders including Gujarat Chief Minister Narendra Modi (online at www.narendramodi.in) and Madhya Pradesh Chief Minister Shivraj Singh Chouhan (www.shivrajsinghchouhan.in) also have their own websites. The BJP also ran an extensive online advertisement campaign, primarily on Google, with search advertisements across 200,000 keywords (including keywords related to Congress leaders), placement advertisements across 50,000 websites, and banner advertisements across 2,000 websites. With almost a billion searches every month, the BJP's campaign was expected to influence up to $75 \%$ of India's Internet users (Sapre, 2009).

The Congress also has a website, which is mainly an online version of its manifesto. Some Congress candidates for parliament including former United Nations Under Secretary Shashi Tharoor and other Congress leaders like the late Andhra Pradesh Chief Minister Y.S.Rajasekhar Reddy have made attempts to leverage the Internet in order to get in touch with voters. One of the authors of this paper is also a co-founder and blogger on www.hamaracongress.com, an independent online forum supportive of the Congress party. This blog enables debate and constructive criticism about national policy and politics and provides a Congress-oriented online counter thrust against other political parties. 
Other parties like the Communist Party of India (Marxist) and the Samajwadi party have also tried to use these new media tools to their advantage. The latter party's use of the Internet is ironic because it promised to ban computers in its manifesto! These Internet based campaigns are not expected to have large-scale impact currently due to inadequate penetration and lack of access in rural and small town India, but they do represent attempts by political parties to engage the voter more directly and convey their message in an undiluted manner.

\subsection{Activism and Political Mobilization Using ICTs}

\subsubsection{Citizens Initiative}

In 2006, a pioneering attempt to harness ICTs to mobilize voters was initiated by a neutral, non-partisan platform called Citizens Initiative, with which one of the authors was actively involved (Gowda, 2007). Its aim was to enrol graduates to register as voters for an election to Karnataka state's bicameral legislature from the Bangalore Graduates constituency, whose unique feature is an electorate restricted to graduates. Because registration was a cumbersome process involving provision of proof of graduation to the election authorities, less than five percent of potentially eligible voters participated in these elections historically. Citizens Initiative launched an online voter enrolment campaign called "End the Apathy" and targeted graduate voters in ICT companies located in Bangalore that employ hundreds of thousands of graduates. The campaign involved these companies' chief executive officers (CEOs) sending an email to their entire staff exhorting them to enrol and vote and offering the assistance of the companies' human resource development departments where needed. Citizens Initiative's website also provided more information about the election and e-enabled the registration process. Voters who enrolled through this process were also assured of information about candidates at the time of the election.

However, Citizens Initiative was limited in its impact, and it managed to register only around 4000 voters, a fraction of the numbers enrolled by political parties using offline methods. One reason for this failure is graduates' general ignorance of the constituency itself (Shile, 2006). Gowda (2007) analyzes the campaign's failure thus: "[T]he "End the Apathy" campaign of Citizens Initiative contained a general, "dogood, be-an-active-citizen" type of message. But this was a message without a messenger, in the sense that there was no candidate for the potential voter to identify with. Hence, voters did not generally put in the effort to register, even though the process was made as simple as was feasible. In contrast, regular parties enrolled voters on behalf of known candidates and that led to a certain focused commitment from their target voters." Citizens Initiative had been constrained to be neutral and non-partisan by CEOs who were only willing to enable and promote an online voter registration process in their companies on that basis. This neutrality may have ensured its failure at mobilizing graduate voters in a constituency explicitly available to them.

\subsubsection{Youth for Equality}

In India, the use of ICTs in a significant manner for political mobilization can be dated to begin with a campaign called Youth for Equality in 2006. This campaign was organized to rally students opposed to the Indian Government's extension of the reservation system (similar to affirmative action but involving quotas) to elite 
government-run institutions of higher and professional education (online at http://www.youthforequality.com/). A small group of volunteers, distributed across various cities, coordinated a series of protests and demonstrations against the government's move using the website as a platform. Youth for Equality rapidly generated online branches across India and in many parts of the world where Indians, particularly students and computer-related professionals, have migrated. Some members of the organization even contested local body elections in Mumbai, albeit unsuccessfully. However, when the Supreme Court ruled in favor of the government's reservation policy (with the proviso that it should be available only to people below a threshold level of income), Youth for Equality fizzled out and has not been able to sustain its initial momentum.

\subsubsection{Lok Paritran}

In 2005-2006, a group of young professionals mainly educated at the elite Indian Institutes of Technology formed a political party called Lok Paritran that emphasized meritocracy (http: / /www.lok-paritran.org/). They mobilized membership and funding through the Internet and spawned support groups on various social networking sites. They followed the unique strategy of plunging into the electoral fray wherever elections were being held with the hope that the excitement associated with elections would draw volunteers and supporters. When Lok Paritran contested the election for the legislature in the state of Tamil Nadu, they were able to draw enough votes in two constituencies to cause the defeat of powerful politicians from mainstream parties (Gowda, 2007). Since the agenda of Lok Paritran favored the middle class, ITsavvy demographic segment, their use of the Internet allowed them substantial gains in Mylapore, one of the urban Chennai constituencies they contested (Muthalaly, 2006). However, while the party did grow and establish a network of branches across the country, it was unable to sustain itself. It has since split into many splinter groups and has been unable to build constructively on its initial electoral forays.

\subsubsection{Bengaluru Unites}

More recently, young people in Bangalore were mobilized in simultaneous protests across Bangalore city by 'Bengaluru Unites' - an initiative spear-headed by one of the authors of this paper. Over the months of February and March, 2009, a series of attacks against women in the name of 'culture' and 'tradition' took place in some parts of Karnataka state, followed by seven attacks on women in Bangalore city, its capital. Sensing the anger, disgust and fear among the people of Bangalore, the campaign utilized the Internet and mass media to successfully organize a series of simultaneous, geographically dispersed protests across Bangalore city against 'moral policing.' The organizing platform was a blog site: www.bengaluru-unites.blogspot. com. A cell phone number was provided to those who wished to join in: upon texting the name of a locality to this number, a reply text would inform them of the nearest protest site. Thousands of college students and working professionals, including many who had never indulged in political action ever, participated in the protests (Srinivas, 2009). The overwhelming numbers of young people participating in the protests (between the ages of 18-35) suggest that ICTs are a particularly powerful medium to mobilize India's youth. 


\subsubsection{The Pink Chaddi Campaign}

Perhaps the most significant and widespread recent use of the online medium in mobilizing real-time political engagement took place in February 2009, with the launch of the 'Pink Chaddi' campaign. Initially set up as a Facebook group, 'The Consortium of Pub-Going, Loose and Forward Women' countered 'moral policing' by the Sri Rama Sene, the same extreme right-wing group that Bengaluru Unites protested against. Its membership rapidly shot to 58,000 and it commenced activities offline as well. In face of widespread protests, and media attention and activism, the extreme right-wing group, the Sri Rama Sene, was forced to back down from its proposed plan of 'forcibly marrying off men and women seen together on Valentine's Day' (Gupta, 2009).

\section{The Indian Political Context}

\subsection{The Evolution of the Indian Polity}

India is the world's largest democracy characterized by periodic polls, universal suffrage and multiparty competition. India also meets the broader definition of an ideal democracy: political and civil freedom, popular sovereignty and political equality (Diamond and Morlino, 2004). Varshney (2000) points out that India's 'deep' democracy satisfies two key criteria of democratic theory: contestation and participation. Contestation is satisfied because elections in India are truly competitive and incumbents are routinely challenged and defeated. Participation is satisfied because all sections of India's population vote or engage with the political process, and historically excluded sections are also finding greater access and representation. Arguably, India has successfully overcome the lack of democracy-enabling conditions such as industrialization, urbanization, mass literacy and a minimum standard of living, as well as serious obstacles to democracy such as religious, linguistic, and ethnic heterogeneity, inequality, and extreme poverty (Gowda and Sridharan, 2007).

Yadav (1999) describes India's electoral system as having gone through three phases since the first democratic election in 1952. The first electoral phase lasted from 1952-67 and was dominated by the Congress party. Its leadership was drawn significantly from the educated, upper castes who had led the movement for independence. This period was marked by low electoral participation and an insignificant and fractured Opposition. In the second phase, which lasted till the 1990s, as per Yadav, the Congress party retained this core position in the electoral system, even as a democratic upsurge brought many new entrants from the middle and "backward" (referring to groups that were historically on the lower rungs of the social status, economic, and educational ladders) classes into 'electoral politics'. The 1990s mark Yadav's Third Phase, a period often described as characterized by intense factionalisation of political space, coupled with excessive political corruption, nongovernance, disorder and instability.

This third phase witnessed decline in the quality of democracy, rise of 'election fatigue,' and disinterest and cynicism with regard to politics among the educated, upper and middle classes (Gowda and Sridharan, 2007). Yadav (1999), however, reads the churning of the 1990s as the signs of a new social order, witnessing the 
ascent to leadership of increasing numbers of citizens from the lower rungs of the social hierarchy--the Other Backward Castes (OBCs) and Dalits. Noting the decline in political involvement of the upper castes and middle classes, Yadav asserts that India defies the textbook rule of political participation whereby the rich and powerful are more likely to vote in elections. In India, an urban, educated, upper-caste citizen is far more likely to refrain from voting when compared to his counterpart amongst rural, uneducated, lower caste voters.

Varshney (2000) agrees that the social base of participation has distinctly shifted downwards - towards the countryside and the lower castes: "If there is any apathy towards voting, it is in India's larger cities and in their more affluent parts." Political theorists have pointed out that India's early politicians had definite Oxbridge backgrounds and they have gradually been replaced by leaders drawn from the lower castes, beginning with the relatively peaceful Dalit revolution in South India (Varshney, 2000). The rise of Dalit and OBC parties in the 1990s led to a reversal of the traditional patterns of political domination as as lower castes increasingly challenged the hegemony of the upper class upper caste English-speaking politician. Jaffrelot (2008) points out that this displacement by OBC and Dalit parties might account for the withdrawal of the middle and upper classes from occupying centrestage in Indian politics.

Another explanation for the withdrawal of the middle and upper classes perhaps lies in India's 'parallel' approaches to governance. India has a complex system of patronage politics where voters consider caste and ethnic ties while voting, and patrons, in turn, respond with personal favors and interventions in bureaucratic functioning to help their supporters identified along lines of caste, language or ethnicity (Chandra, 2004). The rise of lower-caste and Dalit politicians means that upper and middle class voters do not share the same identity-based rapport with their representatives. However, upper-caste, affluent citizens can afford to secede from this form of political engagement by relying on strategies such as bribes, employing a middle man to navigate bureaucratic labyrinths or by using the private sector to meet desired ends -choices that are possibly unavailable to those less privileged.

We argue that the churning associated with the Third Electoral Phase might have unwittingly given rise to a 'Fourth Electoral Phase': marked by a tentative return to political engagement by a rising number of middle classes. Election campaigns in the recently concluded parliament election keenly targeted this traditionally apathetic class. In addition, recent media editorial commentary has suggested that India's urban elite regard the rise of lower caste parties as "disturbing" and unsettling (Mustafa, 2009). We suggest that this discomfort can translate into increased political engagement by the upper castes in an attempt to regain some measure of control over a changing political sphere increasingly dominated by backward caste and class groupings.

Our 'Fourth Electoral Phase' coincides with the Election Commission's redistricting of parliament constituencies to take into account population movements from rural to urban areas. This has increased electoral representation in favor of urban areas. Urban areas have more middle and upper classes when compared with rural areas. The Fifteenth General Election in 2009 is the first parliament election using these newly redrawn constituencies. Its results, surprisingly, indicate that the original figure of the well-educated, foreign-returned, upper class and caste politician might be making a 
comeback. The election of a large number of foreign-educated, well-heeled politicians might partly be because of the return of the middle class voter (though many such politicians have been elected from rural constituencies).

The final feature of the Fourth Phase is its coincidence with India's economic "liberalization." This period, commencing from 1991, has been marked by a lowering of bureaucratic barriers such as licensing requirements for industry, and is credited with unleashing entrepreneurial energies across India. It has been marked by a significant expansion in the numbers of the urban upper and middle classes (Jaffrelot and van der Veer, 2008). This period is also marked by increased ICT-fluency and literacy, with estimates suggesting that by 2020 , approximately $60 \%$ of India's population will be ITenabled (Internet usage figures from www.internetworldstats.com). It is the combination of India's urban upper and middle classes re-engaging with government and utilizing ICTs that enables us to explain the range of ICT-enabled reform and political initiatives that we described in earlier sections of this chapter.

\section{Analysis and Conclusion}

ICTs and the ease with which the middle and upper classes can access and use them may have played a central role in enabling the re-engagement of these classes with the political process (in contrast with the "digital divide" that prevents many poor Indians from engaging with ICTs (Keniston, 2004)). This is in line with Castells' (1998) thesis that electronic communication offers the possibility of enhancing political participation in a wider sphere. Castells (1998) points out that 'online information access and computer mediated communication facilitate the diffusion and retrieval of information, and can enable interaction and debate in an autonomous, electronic forum, bypassing the control of the mainstream media'. He articulates how citizen initiatives can take the lead in this regard: 'More importantly, citizens can form, and are forming, their own political and ideological constellations, circumventing established political structures, thus creating a flexible, adaptable political field' (Castells, 1998, p 350).

However, as India's middle and upper classes begin to harness ICTs in edemocratic initiatives, what stands out is their substantial emphasis on "neutral" reforms and non-partisan interventions. This may be partly influenced by their wariness of being "tainted" through association with mainstream political parties (and sections of the bureaucracy) that are popularly considered to be corrupt. Alternatively, it may reflect a desire on the part of the upper and middle classes to be able to achieve their goals regardless of which political formation is in office. But, as in the case of the Citizens' Initiative drive to register graduate voters, this neutrality can carry within it the seeds of its own destruction. Because there was no candidate who they could identify with and whose agenda they could support passionately, large numbers of potential voters ignored the voter registration drive even when this effort focused on a constituency that consisted only of graduate voters.

Another feature that stands out as common to many of the initiatives we describe (e.g., ADR, PRS, Liberty Institute, etc.) is their focus on information access. This approach limits reform to the provision of information in a non-partisan manner. Once that is accomplished, people are left to make their own judgments and choices. These 
NGOs do not go beyond information provision to lead campaigns that bring about transformative change by pushing political parties to nominate better candidates. Such behavior on the part of these NGOs perhaps reflects a mindset and "business ethic" that privileges a certain clockwork efficiency (Lefebvre, 2008) rather than the messiness of political engagement. (In the case of ADR, however, the emphasis on information provision arose because it considered that to be the only achievable policy goal in the politico-judicial context wherein the reform campaign was conducted (Sastry, 2004)).

Where possible, the upper and middle classes have bypassed the democratic process in their pursuit of efficiency in governance. This is particularly evident in the efforts of the Bangalore Agenda Task Force (BATF), a body constituted by the Government of Karnataka during 1999-2004 to improve the performance of various civic agencies in the city of Bangalore. The members of the BATF included captains of India's information technology industry and BATF was able to effect change because it had the active support of the state's chief minister. It was able to set targets and change the behavior of government agencies without any official authority. This has led to critics raising questions about its legitimacy and its lack of concern for issues affecting the poor (Ghosh Rao, 2005). When the government and chief minister changed, BATF faded away. Of particular interest to our analysis, however, is the fact that one of the key members of the BATF also funded the establishment of the e-Governments Foundation. The e-Governments Foundation's stated goal was to utilize ICTs and geographic information systems to enhance the ability of municipal governments to levy taxes more effectively. Many municipal governments across India have utilized products and services from e-Governments Foundation (e.g., online grievance redressal systems) to enhance the effectiveness of governance and public service delivery.

In analyzing the engagement of elites with politics, Yadav (1999) points to a "Bhasha-English" divide, where "Bhasha" represents the rhetoric of social justice and democratic rights and English refers to the logic of globalization-friendly macroeconomic and bureaucratic management. Yadav argues that the success of the lower castes in the electoral sphere was a mere "consolation" that did not translate into an ability to guide policies. This is because the process of economic liberalization (pushed through by "stealth" (Jenkins, 2004)) had ensured that "most significant economic decisions were removed from the political agenda." Thus, while the lower classes "had the consolation of winning the elections, the other could continue to rule" (Yadav, 1999 p. 2398).

Given that the middle and upper classes are able to substantially achieve their policy goals without going through the rigors of the electoral process, it is not surprising then to see that there is very little attention to active political mobilization that sustains itself over elections and over time. The one example of a party with a middle-class-oriented agenda that utilized ICTs to organize nationwide is Lok Paritran, which we described above. While Lok Paritran gained substantial attention online and in the English language mass media, it did not succeed electorally, and has since split into many splinter groups.

There is only one example of middle class political mobilization, partly using ICTs, that has resulted in the formation of a political party that has won at least one seat in a state assembly election. This is the Lok Satta party in Andhra Pradesh whose 
founder, Jayaprakash Narayan, was recently elected to the state legislature. But Lok Satta explicitly began as a neutral, reform-oriented NGO, built a base of supporters mostly through extensive grassroots activity, and only converted itself into a political party about two years ago. As an NGO it participated actively in Election Watch and used its website to promote electoral reforms. More than ICTs, it is offline mobilization that has been central to its success. A key factor that enabled Lok Satta's only victory was Narayan's choice of Kukatpally constituency, which includes a large number of ICT professionals. Narayan's class background, reformist and nonmainstream-party-driven agenda, and ICT-enabled methods all found favor among such an electorate.

ICTs have clearly been the preferred technology of choice when the upper and middle classes needed to mobilize quickly to respond to particular policy and political developments that ran counter to their class interest or commonly-held values. As described above, Youth for Equality, Bengaluru Unites, and the Pink Chaddi campaign all turned to ICTs as the media of choice for their efforts towards mobilization and advocacy. Upadhya (2007) argues that the Internet and ICTs are natural choice of interface for the middle and upper classes, whose homogenous identity itself was largely constituted through the expansion of the information technology sector. Based on our explorations of ICT use by upper and middle classes, we can conclude that their future political mobilization efforts will centrally involve ICTs. However, as they proceed with their efforts, India's upper and middle classes will need to imagine new forms of inclusive citizen engagement based on ICTs and etools that are accessible and useful to all sections of Indian society and that bring about genuine reform. Only such inclusive efforts will help them overcome what Castells terms the current "legitimacy crisis" of the State (1998, p. 342).

\section{Acknowledgments}

The authors thank Rahul De, Karthik Shashidhar, Tanmay Belavadi, Aditya Sridhar and Simantini Mukherjee for their contributions to earlier drafts of this chapter and thank the anonymous reviewers whose suggestions substantially transformed this chapter.

\section{References}

1. Norris, P.: Deepening Democracy via E-governance. World Public Sector report. United Nations (2004)

2. Gowda, R.: Early Indian Initiatives in E-Democracy. International J. Electronic Governance 1(2), 174-189 (2007)

3. Ramanathan, R.: Fuzzy Electoral Math. Mint (May 22, 2008),

http: / / www. livemint.com/2008/05/22003058/

Fuzzy-electoral-math.html (retrieved July 22, 2009)

4. Pinglay, P.: The websites of India's e-election. BBC Worldwide (May 3, 2009), http://news.bbc.co.uk/2/hi/south_asia/8020522.stm (retrieved May 14, 2009) 
5. Gowda, R., Sridharan, E.: The Consolidation of India's Democracy: The Role of Parties and The Party System, 1947 - 2006. In: Diamond, L., Ganguly, S., Plattner, M.F. (eds.) The State of India's Democracy, pp. 3-26. JHU, Baltimore (2007)

6. Sastry, T.: Electoral Reforms and Citizens' Initiatives. Economic and Political Weekly 39(13) (2004)

7. Bawa, Z.: Transparency and Politics: Politically Aware and Participatory Citizenry. Centre for Internet and Society (2009),

http://www.cis-india.org/research/cis-raw/

histories-of-the-internet/transparency-and-politics/

2009/05/05/internet-politics-and-transparency-2 (retrieved May 11, 2009)

8. Madhukar, C.V.: 46-Day Report Card, The Indian Express (December 24, 2008)

9. Yadav, Y.: The Paradox of Political Representation. Seminar 586 (2008)

10. Srivastava, M., Madhukar, C.V.: His work on bills makes it easy for MPs to take part in debates Mint (May 21, 2007)

11. Gupta, H.: Youth Present Their Ideas to Political Leaders. Citizen Matters (April 22, 2009), http: / /bangalore.citizenmatters.in/articles/view/ 1033-bengaluru-youth-manifesto-elections (retrieved May 9, 2009)

12. Mehra, P.: Mediums and the Message. Mint (March 19, 2009)

13. Mosk, M.: Obama Rewriting Rules For raising Campaign Money Online. The Huffington Post, pp. A06 (March 28, 2008)

14. Sapre, O.: BJP Goes For The Kill, The Economic Times (March 13, 2009), http://economictimes.indiatimes.com/PoliticsNation/ Advani-for-PM-ads-invade-the-net/articleshow/4258123.cms (retrieved May 14, 2009)

15. Gowda, R.: Early Indian Initiatives in E-Democracy. International J. Electronic Governance 1(2), 174-189 (2007)

16. Muthalaly, S.: Lok Paritran Pleased With Its Performance. The Hindu (May 13, 2006), http: //www.hinduonnet.com/2006/05/13/stories/ 2006051322570300 .htm (retrieved May 11, 2009)

17. Srinivas, S.: Bengaluru Unite. In: a Protest Campaign Citizen Matters (February 13, 2009), http://bangalore.citizenmatters.in/articles/view/ 813-bengaluru-unites-protest-campaign (retrieved May 11, 2009)

18. Gupta, H.: Moral Panic in the Media Infochange India (2009), http: / / infochangeindia.org/Media/Related-Features / Moral-panic-in-the-media.html (retrieved May 10, 2009)

19. Diamond, L., Morlino, L.: The Quality of Democracy, pp. 1-37. CDDRL Publication (2004)

20. Varshney, A.: Deeper but Unfinished. Seminar 485 (2000)

21. Yadav, Y.: Electoral Politics. In: The Time Of Change - India's Third Electoral System 1989- 1999. Economic and Political Weekly, vol. 34, pp. 2393-2399 (1999)

22. Jaffrelot, C.: 'Why Should We Vote?'. In: Jaffrelot, C., van der Veer, P. (eds.) Patterns of Middle Class Consumption in India and China, pp. 39-43. SAGE, New Delhi (2008)

23. Chandra, K.: Why Ethnic Parties Succeed: Patronage and Ethnic Head Counts in India. Cambridge University Press, Cambridge (2004)

24. Mustafa, K.: Mayawati: A Dalit's Daughter Strides Towards Delhi. India Together (May 18, 2009), http://www.indiatogether.org/2009/may/soc-mayawati.htm (retrieved May 8, 2009) 
25. Jaffrelot, C., van der Veer, P.: Introduction. In: Jaffrelot, C., van der Veer, P. (eds.) Patterns of Middle Class Consumption in India and China, p. 19. SAGE, New Delhi (2008)

26. Keniston, K.: Introduction: The Four Digital Divides. In: Keniston, K., Kumar, D. (eds.) IT Experience in India: Bridging the Digital Divide, pp. 11-36. SAGE, New Delhi (2004)

27. Castells, M.: The Power of Identity. Blackwell Publishers, Oxford (1998)

28. Lefebvre, B.: The Indian Corporate Hospitals: Touching Middle Class Lives. In: Jaffrelot, C., van der Veer, P. (eds.) Patterns of Middle Class Consumption in India and China, pp. 88-109. SAGE, New Delhi (2008)

29. Ghosh Rao, A.: Public-Private or a Private Public? Promised Partnership of the Bangalore Agenda Task Force. Economic and Political Weekly Special Articles (November 19, 2005)

30. Jenkins, R.: Labour Policy and Second-Generation of Economic Reforms in India. In: Jenkins, R., Khilnani, S. (eds.) The Politics of India's Next Generation of Economic Reforms, Special Issue of India Review, Washington, DC, November 2004, vol. 3(2) (2004)

31. Upadhya, C.: Employment, Exclusion and 'Merit' in the Indian IT Industry. Economic and Political Weekly 42(20), 1863-1868 (2007) 